\title{
Synthesis of Zeolite L. Tuning Size and Morphology
}

\author{
Arantzazu Zabala Ruiz, Dominik Brühwiler, Takayuki Ban, \\ and Gion Calzaferri* \\ Department of Chemistry and Biochemistry, University of Bern, \\ CH-3000 Bern 9, Switzerland
}

Received August 5, 2004; accepted August 12, 2004

Published online December 6, 2004 C Springer-Verlag 2004

\begin{abstract}
Summary. A convenient synthesis of zeolite $\mathrm{L}$ is presented. The size of the crystals can be tuned between 30 and $6000 \mathrm{~nm}$, spanning a volume range of seven orders of magnitude. The zeolite L crystals, which typically feature a cylindrical morphology, are synthesized with various aspect ratios ranging from elongated to disc-shaped. The importance of obtaining zeolite crystals with well-defined size and morphology is discussed in view of potential applications of zeolite L containing organic dye molecules as guests.
\end{abstract}

Keywords. Hydrothermal synthesis; Inclusion compounds; Nanostructures; Zeolites; Electron microscopy.

\section{Introduction}

Zeolites are crystalline aluminosilicates featuring defined channels and cavities. The ability to accommodate various organic and inorganic species while being transparent in the UV-Vis-NIR makes zeolites ideal host materials for supramolecular organization $[1,2]$. In many cases the confinement of molecules in zeolites and the catalytic activity of surface adsorption sites lead to interesting photochemical phenomena not observed in solution [3].

Zeolite L possesses one-dimensional channels arranged in a hexagonal pattern (see Fig. 1) [4]. High-resolution electron microscopy has been used by Ohsuna et al. [5] to image the surface structures of zeolite $\mathrm{L}$ and to advance the understanding of growth processes and defects. Materials obtained by the inclusion of organic dye molecules into the channels of zeolite $\mathrm{L}$ feature a variety of intriguing properties, ranging from increased dye stability to photonic antenna functions and optical anisotropy [6]. The potential of dye-zeolite L composites is fully

\footnotetext{
* Corresponding author. E-mail: gion.calzaferri@iac.unibe.ch
} 


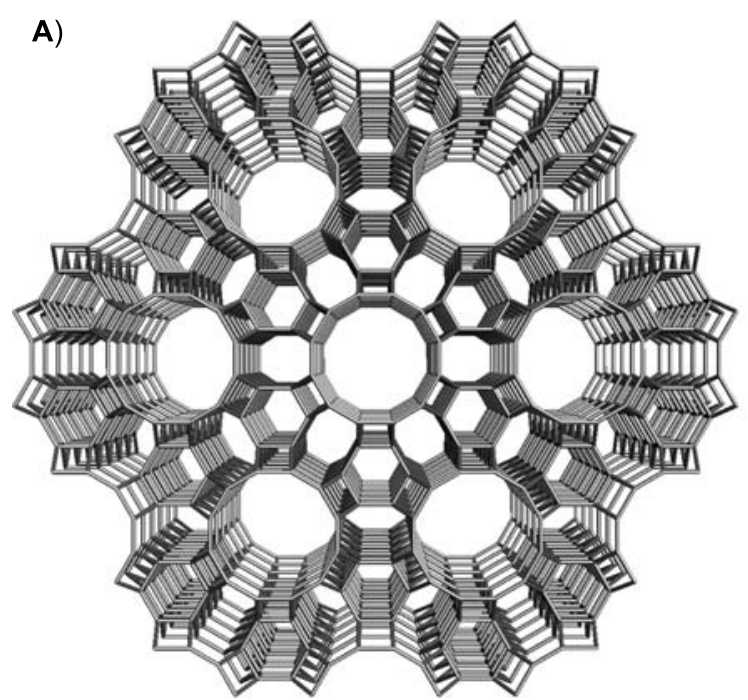

B)

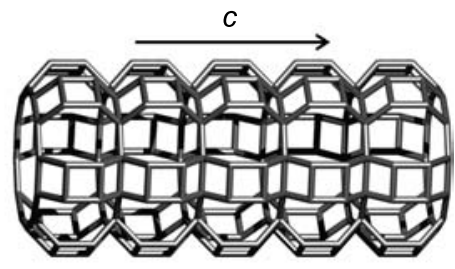

C)

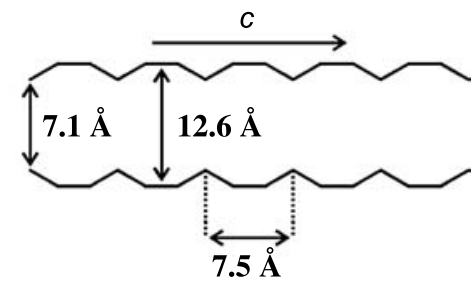

Fig. 1. A) Zeolite L framework projected along the $c$-axis; B) side view of the main channel; C) its dimensions

exploited by tuning the size and morphology of the zeolite crystals according to the requirements of a given application. Small dye-loaded zeolite crystals $(<300 \mathrm{~nm})$ are potential functional pigments, whereas large crystals $(>1 \mu \mathrm{m})$ are used for the investigation of dye arrangements by optical microscopy [7, 8]. Discshaped crystals, i.e., crystals of low aspect ratio (=length/diameter), lead to oriented monolayers upon deposition onto a substrate, whereas crystals of high aspect ratio allow for alignment on microstructured surfaces, thereby opening possibilities for producing macroscopic areas of oriented guest molecules. The successful assembly of aligned zeolite monolayers largely depends on the ability to obtain zeolite crystals with narrow size distribution and well-defined morphology [9].

\section{Results and Discussion}

Despite the very useful collection of verified syntheses of zeolitic materials [10], recipes for zeolite synthesis are often difficult to follow for the non-specialist and frequently involve elaborate equipment. We will in the following present a convenient and reproducible procedure for the synthesis of zeolite L. Starting from a standard routine (see Fig. 2), the size and morphology of the products are tuned by changing the gel composition $\left(\mathrm{H}_{2} \mathrm{O} / \mathrm{SiO}_{2}\right.$ and $\mathrm{K}_{2} \mathrm{O} / \mathrm{SiO}_{2}$ ratios) as well as other synthesis parameters such as the type of silica source and crystallization with or without agitation (dynamic or static). Table 1 gives an overview of the obtained products. Details concerning the separate steps of the syntheses are outlined in the Experimental. We have divided the products according to their particle size into three groups which are discussed in the following subsections. 


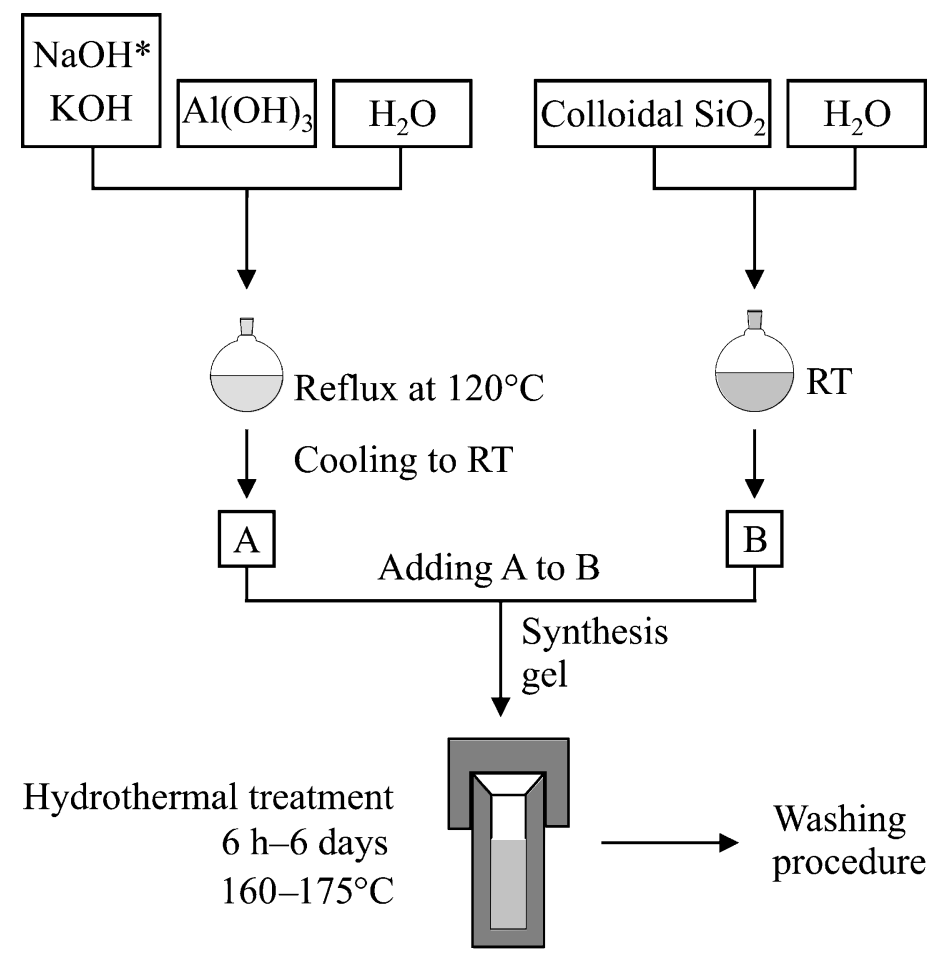

Fig. 2. General scheme of the zeolite L synthesis procedure; details are given in the Experimental

Table 1. Synthesis and product characteristics

\begin{tabular}{|c|c|c|c|c|c|c|c|}
\hline \multirow{2}{*}{$\begin{array}{l}\text { Crystal length } \\
\text { along } c \text {-axis/nm }\end{array}$} & \multirow{2}{*}{$\begin{array}{l}\text { Starting gel composition } \\
\mathrm{K}_{2} \mathrm{O}: \mathrm{Al}_{2} \mathrm{O}_{3}: \mathrm{SiO}_{2}: \mathrm{H}_{2} \mathrm{O}\end{array}$} & \multicolumn{3}{|c|}{ Crystallization } & \multirow{2}{*}{$\begin{array}{l}\text { Silica } \\
\text { source }^{b}\end{array}$} & \multirow[t]{2}{*}{ Variation } & \multirow{2}{*}{$\begin{array}{l}\text { Aspect } \\
\text { ratio }^{\mathrm{c}}\end{array}$} \\
\hline & & $t / \mathrm{h}$ & $T /{ }^{\circ} \mathrm{C}$ & cond. $^{\mathrm{a}}$ & & & \\
\hline $30-70$ & $9.34: 1.00: 20.20: 412.84$ & 6 & 170 & $\mathrm{~d}$ & $\mathrm{AO}$ & - & 1.0 \\
\hline $200-550$ & 3.17:1.00:9.83:168.52 & 42 & 160 & $\mathrm{~d}$ & $\mathrm{AO}$ & $\mathrm{Mg}^{2+}$ & 0.6 \\
\hline $400-1300$ & $\begin{array}{l}2.55: 1.00: 9.83: 165.60 \\
2.70: 1.00: 9.83: 165.60 \\
\text { 2.83:1.00:9.83:165.60 } \\
3.13: 1.00: 9.83: 165.60\end{array}$ & $\begin{array}{l}42 \\
42 \\
42 \\
42\end{array}$ & $\begin{array}{l}160 \\
160 \\
160 \\
160\end{array}$ & $\begin{array}{l}\mathrm{d} \\
\mathrm{d} \\
\mathrm{d} \\
\mathrm{d}\end{array}$ & $\begin{array}{l}\mathrm{AO} \\
\mathrm{AO} \\
\mathrm{AO} \\
\mathrm{AO}\end{array}$ & $\begin{array}{l}\text { Increase of } \\
\text { alkalinity }\end{array}$ & $\begin{array}{l}1.3 \\
1.2 \\
0.8 \\
0.6\end{array}$ \\
\hline $250-450$ & $5.40: 5.50: 1.00: 30.00: 416.08^{\mathrm{d}}$ & 48 & 160 & $\mathrm{~d}$ & $\mathrm{~L}$ & $\mathrm{NaOH}$ & 0.3 \\
\hline $1000-3000$ & $\begin{array}{l}2.99: 1.00: 10.70: 182.00 \\
2.99: 1.00: 10.70: 194.60 \\
2.99: 1.00: 10.70: 199.20 \\
2.99: 1.00: 10.70: 250.70 \\
2.99: 1.00: 10.70: 299.70 \\
2.99: 1.00: 10.70: 332.40 \\
2.55: 1.00: 9.72: 161.30\end{array}$ & $\begin{array}{l}144 \\
144 \\
144 \\
144 \\
144 \\
144 \\
144\end{array}$ & $\begin{array}{l}160 \\
160 \\
160 \\
160 \\
160 \\
160 \\
160\end{array}$ & $\begin{array}{l}\mathrm{s} \\
\mathrm{s} \\
\mathrm{s} \\
\mathrm{s} \\
\mathrm{s} \\
\mathrm{s} \\
\mathrm{s}\end{array}$ & $\begin{array}{l}\text { AK } \\
\text { AK } \\
\text { AK } \\
\text { AK } \\
\text { AK } \\
\text { AK } \\
\text { AK }\end{array}$ & $\begin{array}{l}\text { Increase of } \\
\mathrm{H}_{2} \mathrm{O} \text { content }\end{array}$ & $\begin{array}{l}1.1 \\
1.1 \\
1.2 \\
1.8 \\
1.7 \\
1.2 \\
2.0\end{array}$ \\
\hline $4000-6000$ & 2.21:1.00:9.00:164.60 & 72 & 175 & $\mathrm{~s}$ & $\mathrm{~L}$ & $\mathrm{Al}$ source & 2.6 \\
\hline
\end{tabular}

${ }^{\mathrm{a}}$ Crystallization conditions: $\mathrm{d}=$ dynamic, $\mathrm{s}=$ static; ${ }^{\mathrm{b}} \mathrm{AO}=$ Aerosil $\mathrm{OX}-50, \mathrm{AK}=$ Aerosil $\mathrm{K}-330, \mathrm{~L}=\mathrm{Ludox}$ $\mathrm{HS}-40 ;{ }^{c}$ calculated from the mean length and the mean diameter; ${ }^{\mathrm{d}} 5.40 \mathrm{~K}_{2} \mathrm{O}-5.50 \mathrm{Na}_{2} \mathrm{O}-1.00 \mathrm{Al}_{2} \mathrm{O}_{3}-30.00$ $\mathrm{SiO}_{2}-427.00 \mathrm{H}_{2} \mathrm{O}$ 


\section{Small Crystals}

To obtain zeolite L nanocrystals we performed the synthesis as reported in Ref. [11], except for changes in the starting gel composition and the silica source (Aerosil OX-50). Dynamic crystallization conditions were applied for $6 \mathrm{~h}$ at $170^{\circ} \mathrm{C}$. A highly alkaline molar composition $9.34 \mathrm{~K}_{2} \mathrm{O}-1.00 \mathrm{Al}_{2} \mathrm{O}_{3}-20.20 \mathrm{SiO}_{2}-$ $412.84 \mathrm{H}_{2} \mathrm{O}$ was used, yielding zeolite crystals with a size of about $30 \mathrm{~nm}$ which tend to agglomerate into larger clusters of 80 to $100 \mathrm{~nm}$ [12]. Figure 3 shows the scanning electron microscopy image (SEM) and the transmission electron microscopy image (TEM) of these crystals, the latter even resolving the channel structure. The X-ray diffraction (XRD) pattern showed the line broadening expected for such a small particle size.
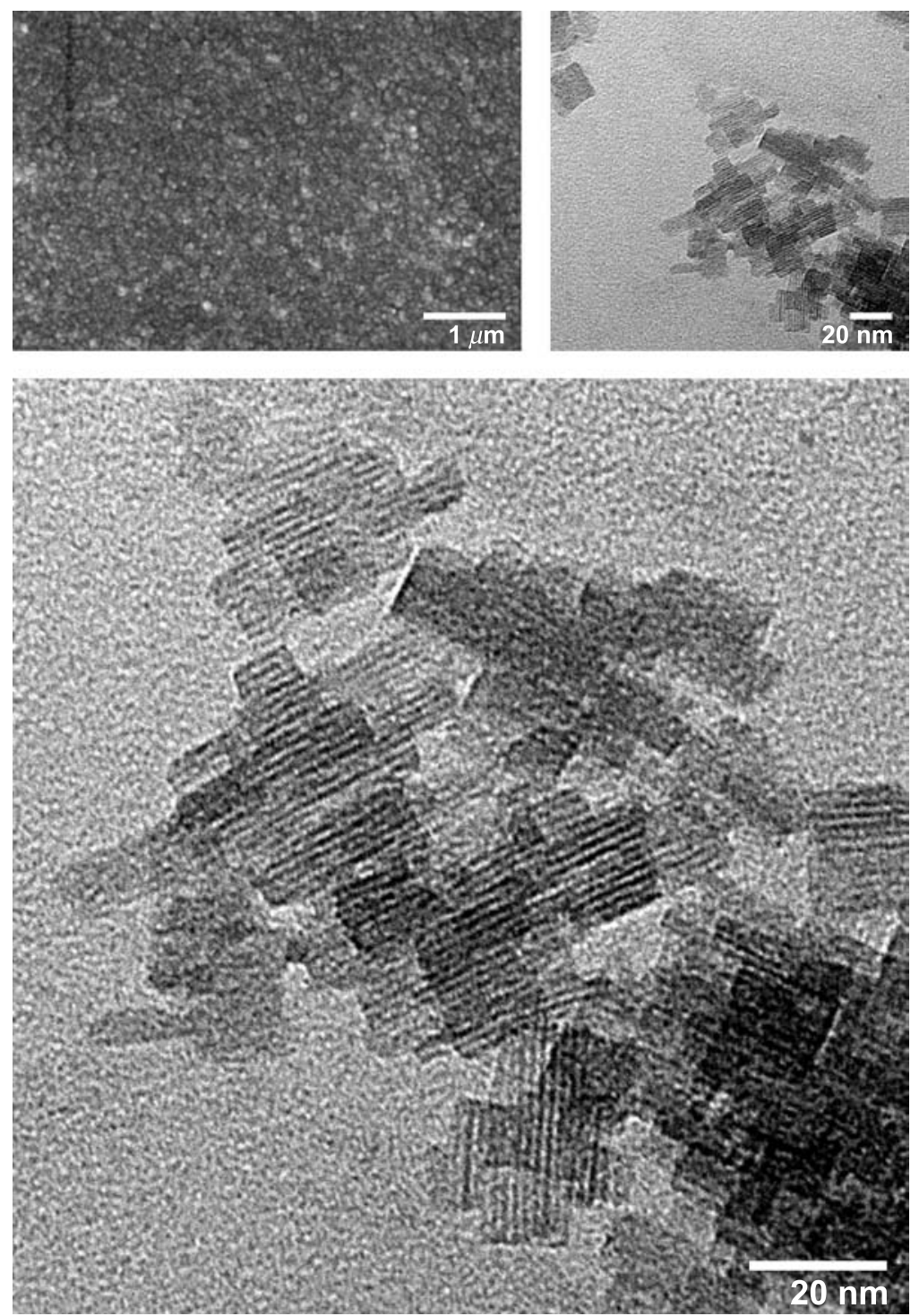

Fig. 3. TEM images of zeolite L nanocrystals; top left: SEM image 

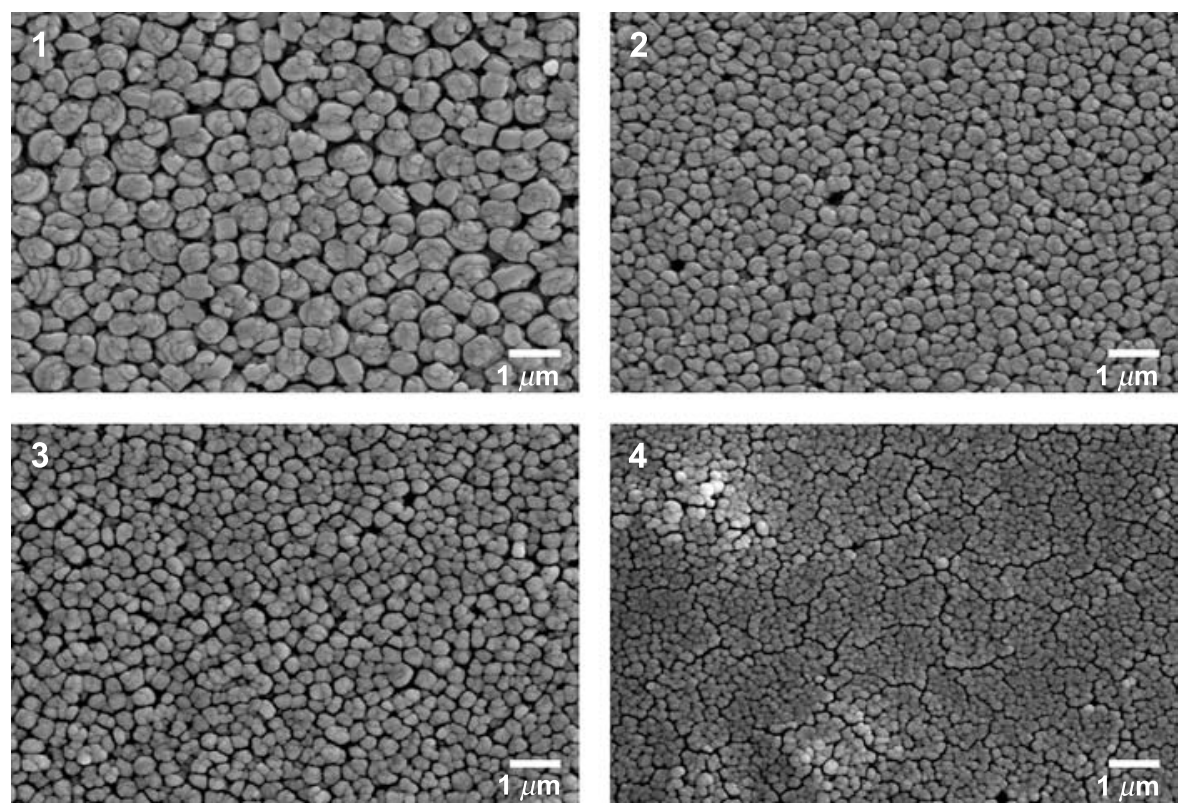

Fig. 4. SEM images of zeolite L crystals synthesized with the same gel composition and seeded with different amounts of $\mathrm{Mg}^{2+}:$ 1) $0 \mathrm{ppm}$, 2) $5 \mathrm{ppm}$, 3) $10 \mathrm{ppm}$, 4) $20 \mathrm{ppm}$

\section{Medium Size Crystals}

Crystals 200-550 nm: 'cauliflower like' morphology. A synthesis mixture was prepared as described in Ref. [13] with a molar composition of $3.17 \mathrm{~K}_{2} \mathrm{O}-1.00$ $\mathrm{Al}_{2} \mathrm{O}_{3}-9.83 \mathrm{SiO}_{2}-168.52 \mathrm{H}_{2} \mathrm{O}$. The silica suspension (Aerosil OX-50) was seeded with $\mathrm{Mg}^{2+}\left(\mathrm{Mg}\left(\mathrm{NO}_{3}\right)_{2} \cdot 6 \mathrm{H}_{2} \mathrm{O}\right)$ and the synthesis mixture was crystallized at $160^{\circ} \mathrm{C}$ for $42 \mathrm{~h}$ under dynamic conditions. The same product was obtained upon reducing the crystallization time and increasing the rotation speed by a factor of two. Figure 4 shows the influence of the addition of small amounts of $\mathrm{Mg}^{2+}$ to the reaction mixture. The introduction of $\mathrm{Mg}^{2+}$ into the zeolite synthesis mixture reduces the occurrence of impurity phases and stimulates the formation of small crystals. Unfortunately, part of the cylinder morphology is lost at the same time. Agglomeration of zeolite crystals occurs at $\mathrm{Mg}^{2+}$ concentrations above $10 \mathrm{ppm}$.

Crystals $400-1300 \mathrm{~nm}$. It has been reported that the particle size of zeolite L decreases with increasing alkalinity, i.e., increasing $\mathrm{K}_{2} \mathrm{O} / \mathrm{Al}_{2} \mathrm{O}_{3}$ ratio [14]. We studied this effect by starting with the formal composition of $2.55 \mathrm{~K}_{2} \mathrm{O}-1.00$ $\mathrm{Al}_{2} \mathrm{O}_{3}-9.83 \mathrm{SiO}_{2}-165.60 \mathrm{H}_{2} \mathrm{O}$ and increasing the $\mathrm{K}_{2} \mathrm{O}$ content in four steps up to 3.13 (using Aerosil OX-50 as silica source). The synthesis mixtures were crystallized at $160^{\circ} \mathrm{C}$ for $42 \mathrm{~h}$ under dynamic conditions. Figure 5 shows that increasing the alkalinity results not only in crystals of lower aspect ratio, but also in an increasing intergrowth at the crystal ends. Despite the fact that this intergrowth reduces the morphological quality of the crystals, the overall cylindrical shape is well preserved.

Dynamic and static crystallization conditions appeared to influence the morphology of crystals larger than $1000 \mathrm{~nm}$, whereas there was no significant influence on crystals below this size. Figure 6 shows SEM images of two samples prepared 

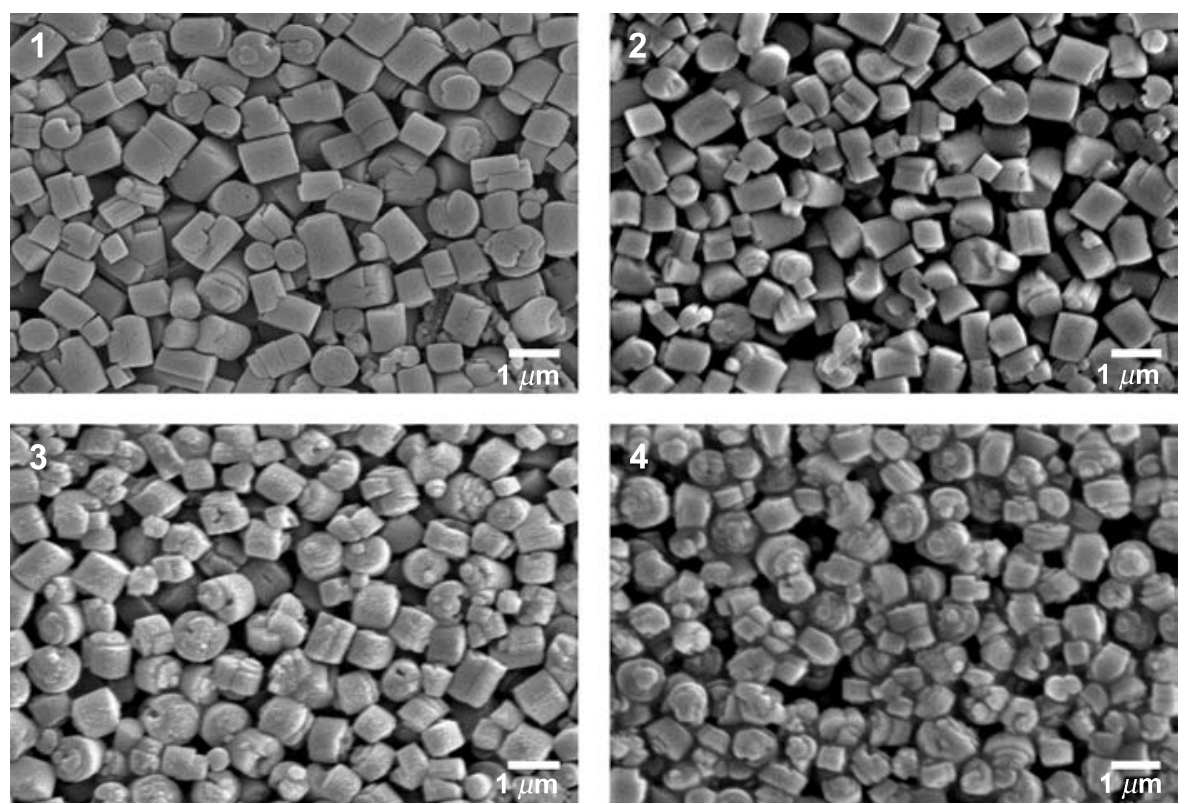

Fig. 5. SEM images of zeolite $\mathrm{L}$ crystals synthesized with the gel composition $a \mathrm{~K}_{2} \mathrm{O}-1.00 \mathrm{Al}_{2} \mathrm{O}_{3}-$ $9.83 \mathrm{SiO}_{2}-165.60 \mathrm{H}_{2} \mathrm{O}$; 1) $a=2.55$, 2) $\left.a=2.70,3\right) a=2.83$, 4) $a=3.13$
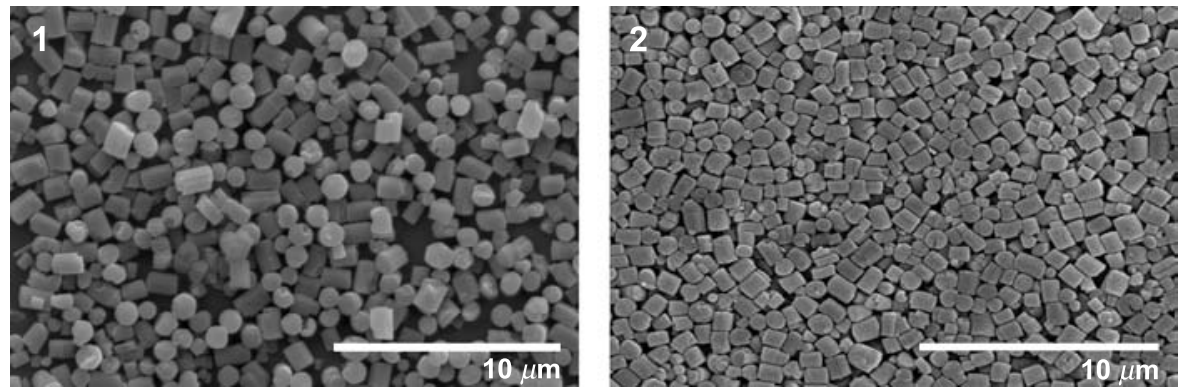

Fig. 6. $\mathrm{SEM}$ images of zeolite $\mathrm{L}$ crystals synthesized with the gel composition $2.55 \mathrm{~K}_{2} \mathrm{O}-1.00 \mathrm{Al}_{2} \mathrm{O}_{3}-$ $9.83 \mathrm{SiO}_{2}-165.60 \mathrm{H}_{2} \mathrm{O}$ and crystallized 1) under static conditions, 2) under dynamic conditions

with the same starting gel composition, but with different crystallization conditions. Obviously, dynamic crystallization conditions yield a product of lower quality.

Crystals 250-450 nm: disc-shaped morphology. A synthesis mixture with the composition $5.40 \mathrm{~K}_{2} \mathrm{O}-5.50 \mathrm{Na}_{2} \mathrm{O}-1.00 \mathrm{Al}_{2} \mathrm{O}_{3}-30.00 \mathrm{SiO}_{2}-416.08 \mathrm{H}_{2} \mathrm{O}$ [15] was prepared. Dynamic crystallization conditions were applied at $160^{\circ} \mathrm{C}$ for $48 \mathrm{~h}$. The best results, i.e., a homogeneous distribution of disc-shaped zeolite L crystals, were obtained with Ludox as the silica source (see Fig. 7).

\section{Large Crystals}

Crystals $1-3 \mu \mathrm{m}$. Crystals with cylindrical morphology were obtained by starting with a gel composition of $2.99 \mathrm{~K}_{2} \mathrm{O}-1.00 \mathrm{Al}_{2} \mathrm{O}_{3}-10.70 \mathrm{SiO}_{2}-182.00 \mathrm{H}_{2} \mathrm{O}$ and increasing 

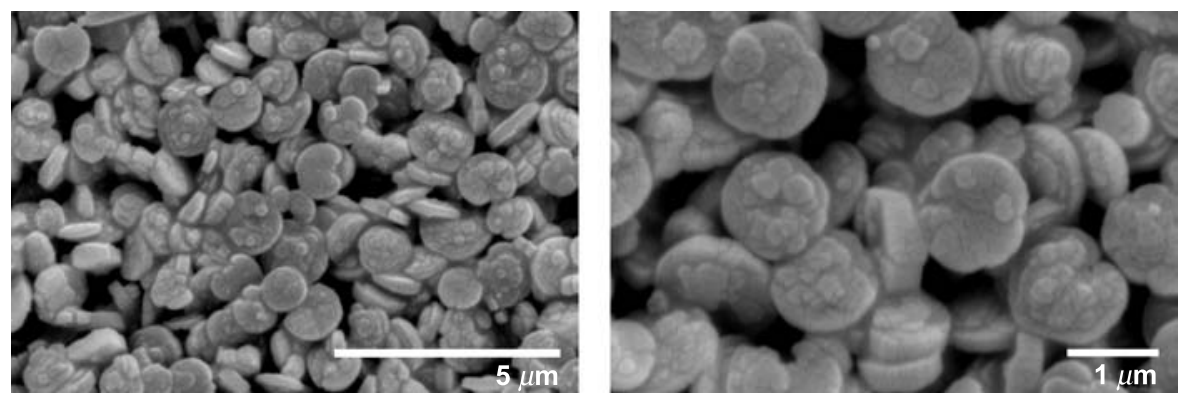

Fig. 7. SEM images of disc-shaped zeolite L crystals

the amount of water in six steps up to 332.40 (using Aerosil K-330 as silica source). The synthesis mixtures were crystallized at $160^{\circ} \mathrm{C}$ for 6 days under static conditions. By increasing the water content of the starting gel we were able to increase the size of the crystals without reducing the morphological quality (see Fig. 8).
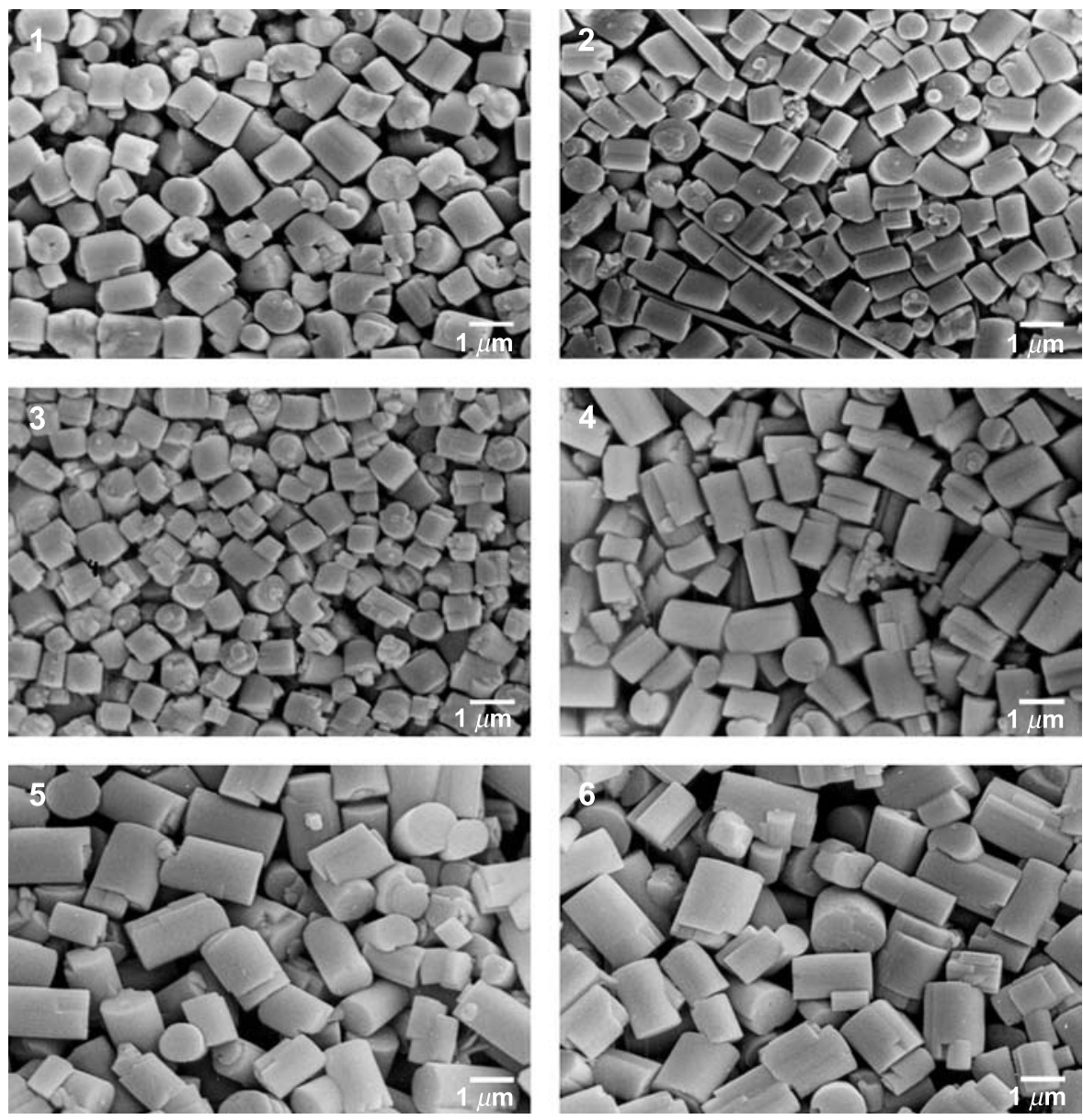

Fig. 8. SEM images of zeolite $\mathrm{L}$ crystals synthesized with the gel composition $2.99 \mathrm{~K}_{2} \mathrm{O}-1.00$ $\mathrm{Al}_{2} \mathrm{O}_{3}-10.70 \mathrm{SiO}_{2}-d \mathrm{H}_{2} \mathrm{O}$; 1) $d=182.00$, 2) $d=194.60$, 3) $d=199.20$, 4) $d=250.70$, 5) $d=299.70$, 6) $d=332.40$ 

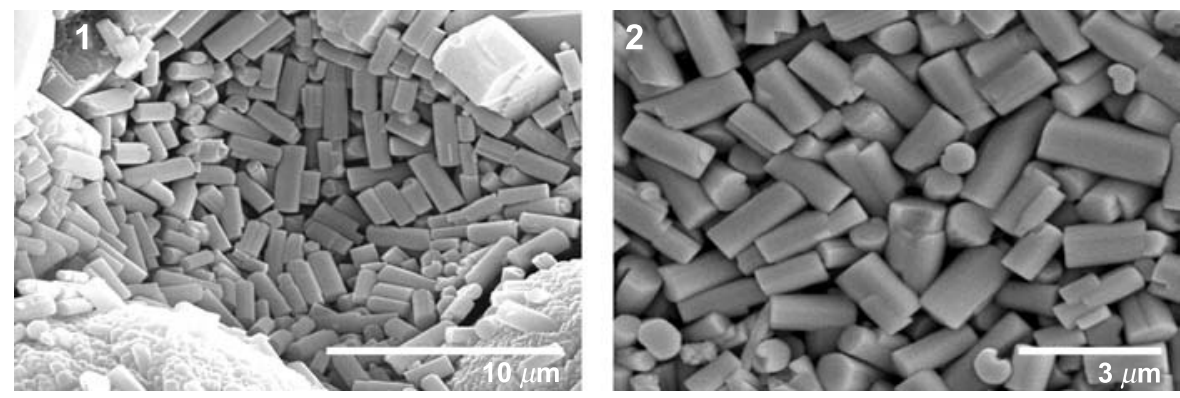

Fig. 9. SEM images of zeolite $\mathrm{L}$ crystals synthesized with the gel composition $2.55 \mathrm{~K}_{2} \mathrm{O}-1.00$ $\mathrm{Al}_{2} \mathrm{O}_{3}-9.72 \mathrm{SiO}_{2}-161.30 \mathrm{H}_{2} \mathrm{O} ; 1$ ) product obtained after crystallization and before separation;

2) after separation from the impurity phase by sedimentation
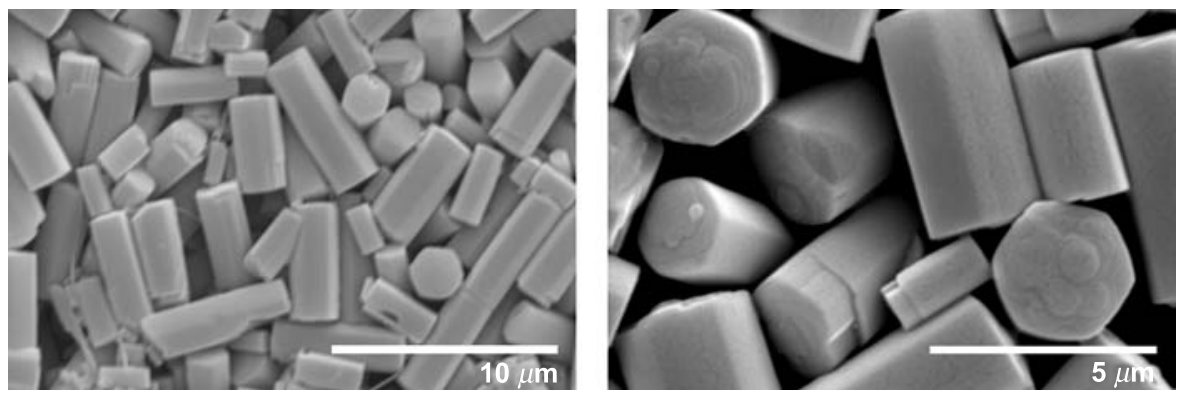

Fig. 10. SEM images of large zeolite L crystals

A composition of $2.55 \mathrm{~K}_{2} \mathrm{O}-1.00 \mathrm{Al}_{2} \mathrm{O}_{3}-9.72 \mathrm{SiO}_{2}-161.30 \mathrm{H}_{2} \mathrm{O}$ resulted in $3 \mu \mathrm{m}$ cylindrical zeolite $\mathrm{L}$ crystals which were obtained together with an impurity phase. The zeolite L crystals were separated from the impurity phase by sedimentation (see Fig. 9).

Crystals 4-6 $\mu \mathrm{m}$. We followed a slightly different procedure to obtain these crystals, starting with a molar composition of $2.21 \mathrm{~K}_{2} \mathrm{O}-1.00 \mathrm{Al}_{2} \mathrm{O}_{3}-9.00 \mathrm{SiO}_{2}-$ $164.60 \mathrm{H}_{2} \mathrm{O}$. A homogeneous distribution of cylindrical crystals with hexagonal cross-section and smooth surfaces were obtained (see Fig. 10). Details are given in the Experimental.

The size of zeolite L crystals can be tuned in the range of 30 to $6000 \mathrm{~nm}$ by variation of a convenient standard procedure. By increasing the alkalinity for a given molar composition, crystals smaller than $1 \mu \mathrm{m}$ were obtained, although the control of the morphology was difficult in this case. Well-shaped cylindrical crystals larger than $1 \mu \mathrm{m}$ were prepared by increasing the amount of water for a given molar composition. Static conditions during crystallization appeared to be ideal for this size regime, whereas no significant difference between static and dynamic conditions was observed for smaller crystals. Zeolite L crystals are usually obtained with aspect ratios above one. We have shown that by careful control of the starting gel composition and the crystallization conditions, as well as an appropriate choice of the silica source, disc-shaped crystals can be synthesized. A discshaped morphology is an important prerequisite for the preparation of oriented 
monolayers of zeolite $\mathrm{L}$ and therefore essential for optimizing the use of dyezeolite composites as photonic antenna systems. Transport of electronic excitation energy by the chains of dye molecules occurs preferentially along the main channels, i.e., along the $c$-axis of dye-loaded zeolite L [6]. An arrangement consisting of zeolite $\mathrm{L}$ crystals oriented with their $c$-axes perpendicular to a substrate is thus desirable for the efficient transport of electronic excitation energy towards the zeolite-substrate interface. We have found that the morphology of the zeolite $\mathrm{L}$ crystals determines the degree of orientation. Whereas an average aspect ratio of 1.3 resulted in monolayers with only $45 \%$ of the crystals in the desired orientation, disc-shaped zeolites with an aspect ratio of 0.3 gave monolayers with close to perfect orientation. The combination of such oriented antennae with a semiconducting substrate is of considerable interest for the preparation of sensitized solar cells and the development of novel light emitting diodes (LEDs) [16]. Embedding of dye-loaded zeolite nanocrystals into thin film solar cells is another possibility to achieve sensitization. Concerning the potential applications of guest-zeolite composites, the control of the size and morpholgy of the zeolitic host is in any case essential for achieving an ideal interaction with external devices.

The synthesis of large zeolite L crystals with well-defined morphology has proven to be especially useful for analytical purposes by allowing for a detailed analysis of the distribution and interaction (energy transfer processes) of guest molecules by time- and space-resolved fluorescence measurements [7] and by offering possibilities for visualizing the intrachannel diffusion of dye molecules [17].

\section{Experimental}

\section{Materials}

We have tested three different silica sources: Two kinds of colloidal silica sol (Ludox HS-40 from Aldrich, $40 \% \mathrm{SiO}_{2}$ and Aerosil K-330 from Degussa, 30\% $\mathrm{SiO}_{2}$ ) and fine silica powder (Aerosil OX50 from Degussa). For the latter, a colloidal suspension containing $30 \% \mathrm{SiO}_{2}$ was freshly prepared before the synthesis. Two different alumina sources were used: Aluminum hydroxide (Fluka, purum $>99 \%$ ) and aluminum powder (Fluka, purum $>99 \%$ ), the latter being only used for one specific synthesis. To introduce alkali metal cations we used KOH (Fluka, Micro Select pellets, $\geq 86 \%$ ) and, depending on the requirements, $\mathrm{NaOH}$ (Merck, pellets GR for analysis, >99\%). Throughout the synthesis doubly distilled water was used.

\section{Calculations}

In order to achieve a high reproducibility, the composition of the starting gel has to be strictly adhered to. In the zeolite literature there are, however, different procedures to calculate the required amounts of chemicals from a given gel composition. In many cases the assumptions on which these procedures are based are not clearly set forth. In the following we will therefore describe in detail our procedure to calculate the amounts of required starting material for a given molar composition $a \mathrm{~K}_{2} \mathrm{O}-b \mathrm{Al}_{2} \mathrm{O}_{3}-c$ $\mathrm{SiO}_{2}-d \mathrm{H}_{2} \mathrm{O}$. It is important to note that the composition of the reaction mixture is given as a ratio of oxides. Hydroxides must therefore be considered as oxides plus water, e.g., $\mathrm{KOH}$ results in $1 / 2 \mathrm{~K}_{2} \mathrm{O}$ and $1 / 2 \mathrm{H}_{2} \mathrm{O}$. The amount of water introduced into the reaction mixture by the hydroxides has to be 
accounted for. The required amounts of $\mathrm{KOH}, \mathrm{Al}(\mathrm{OH})_{3}, \mathrm{SiO}_{2}$, and $\mathrm{H}_{2} \mathrm{O}$ are given by Eqs. (5)-(8) based on Eqs. (1)-(4).

$$
\begin{gathered}
\mathrm{Mol}_{\mathrm{KOH}}=2 a \\
\mathrm{Mol}_{\mathrm{Al}(\mathrm{OH})_{3}}=2 b \\
\mathrm{Mol}_{\mathrm{SiO}_{2}}=c \\
\mathrm{Mol}_{\mathrm{TotH}_{2} \mathrm{O}}=d \\
\text { Weight }_{\mathrm{KOH}}=\frac{\mathrm{Mol}_{\mathrm{KOH}} \cdot \mathrm{MW}_{\mathrm{KOH}}}{\mathrm{P}_{\mathrm{KOH}}} \\
\text { Weight }_{\mathrm{Al}_{(\mathrm{OH})_{3}}}=\frac{\mathrm{Mol}_{\mathrm{Al}_{(}(\mathrm{OH})_{3}} \cdot \mathrm{MW}_{\mathrm{Al}(\mathrm{OH})_{3}}}{\mathrm{P}_{\mathrm{Al}(\mathrm{OH})_{3}}} \\
\mathrm{Weight}_{\mathrm{SiO}_{2}}=\mathrm{Mol}_{\mathrm{SiO}_{2}} \cdot \mathrm{MW}_{\mathrm{SiO}_{2}} \\
\text { Weight }_{\mathrm{TotH}_{2} \mathrm{O}}=\mathrm{Mol}_{\mathrm{H}_{2} \mathrm{O}} \cdot \mathrm{MW}_{\mathrm{H}_{2} \mathrm{O}}
\end{gathered}
$$

$\mathrm{MW}_{\mathrm{KOH}}, \mathrm{MW}_{\mathrm{Al}(\mathrm{OH})_{3}}, \mathrm{MW}_{\mathrm{SiO}_{2}}$, and $\mathrm{MW}_{\mathrm{H}_{2} \mathrm{O}}$ are the molar masses. $\mathrm{P}_{\mathrm{KOH}}, \mathrm{P}_{\mathrm{Al}(\mathrm{OH})_{3}}$, and $\mathrm{P}_{\mathrm{SiO}_{2}}$ are the respective purities. $\mathrm{P}_{\mathrm{SiO}_{2}}$ specifically refers to the $\mathrm{SiO}_{2}$ content of the silica suspension (see below). The total amount of water is distributed among the silica suspension and the potassium-aluminate solution as follows by Eqs. (9) and (10).

$$
\begin{aligned}
\text { Weight }_{\mathrm{H}_{2} \mathrm{OSiO}} \text { susp } & =\frac{\text { Weight }_{\mathrm{SiO}_{2}}\left(1-\mathrm{P}_{\mathrm{SiO}_{2}}\right)}{\mathrm{P}_{\mathrm{SiO}_{2}}} \\
\text { Weight }_{\mathrm{H}_{2} \mathrm{OKAl}}=\text { Weight }_{\mathrm{TotH}_{2} \mathrm{O}}- & \text { Weight }_{\mathrm{H}_{2} \mathrm{OSiO} \text { Susp }_{2}}+\text { Weight }_{\mathrm{Al}(\mathrm{OH})_{3}}\left(1-\mathrm{P}_{\mathrm{Al}(\mathrm{OH})_{3}}\right) \\
& + \text { Weight }_{\mathrm{KOH}}\left(1-\mathrm{P}_{\mathrm{KOH}}\right)+\frac{1}{2} \cdot \mathrm{Mol}_{\mathrm{KOH}} \cdot \mathrm{MW}_{\mathrm{H}_{2} \mathrm{O}} \\
& \left.+\frac{3}{2} \cdot \mathrm{Mol}_{\mathrm{Al}(\mathrm{OH})_{3}} \cdot \mathrm{MW}_{\mathrm{H}_{2} \mathrm{O}}\right]
\end{aligned}
$$

The total weight of the starting gel is then given by Eq. (11).

$$
\text { Weight }_{\text {Tot }}=\text { Weight }_{\mathrm{KOH}}+\text { Weight }_{\mathrm{Al}(\mathrm{OH})_{3}}+\text { Weight }_{\mathrm{SiO}_{2}}+\text { Weight }_{\mathrm{H}_{2} \mathrm{OSiO}_{2} \text { susp }}+\text { Weight }_{\mathrm{H}_{2} \mathrm{OKAl}}
$$

The total weight can be scaled to the capacity of the crystallization vessels. We typically worked with $40 \mathrm{~g}$ of starting gel. The addition of further hydroxides to the synthesis mixture ( $\mathrm{NaOH}$ for the preparation of disc-shaped crystals) has to be taken into account accordingly.

\section{Synthesis}

Zeolite L crystals were synthesized in a hydrothermal process, i.e., crystallization took place in an aqueous system containing the necessary reactants at high temperatures. Figure 2 illustrates the standard procedure. Calculated amounts of aluminum hydroxide, potassium hydroxide, and, in specific cases sodium hydroxide, were added to a precise amount of water and refluxed for $3 \mathrm{~h}$ at $120^{\circ} \mathrm{C}$ resulting in a clear solution. A silica suspension was prepared separately with a calculated amount of colloidal silica when Ludox was used. For silica powder, we added a calculated amount of silica to water and suspended it for $15 \mathrm{~min}$ at $18000 \mathrm{~min}^{-1}$ (Turrax mixer, IKA). This suspension was left between 0.5 to $1 \mathrm{~h}$ and again mixed for $10 \mathrm{~min}$ before use. After letting the potassium (sodium) 

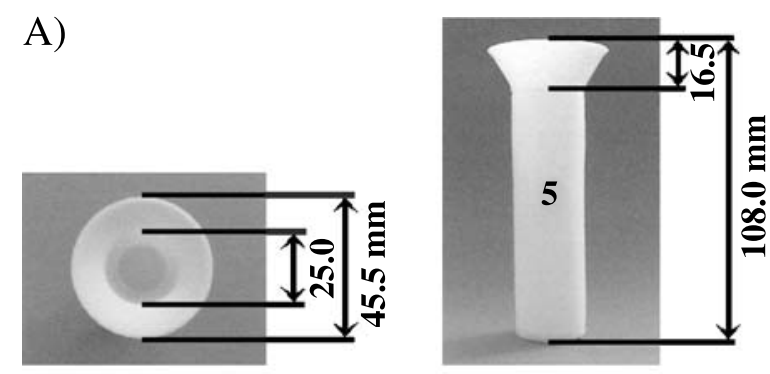

B)
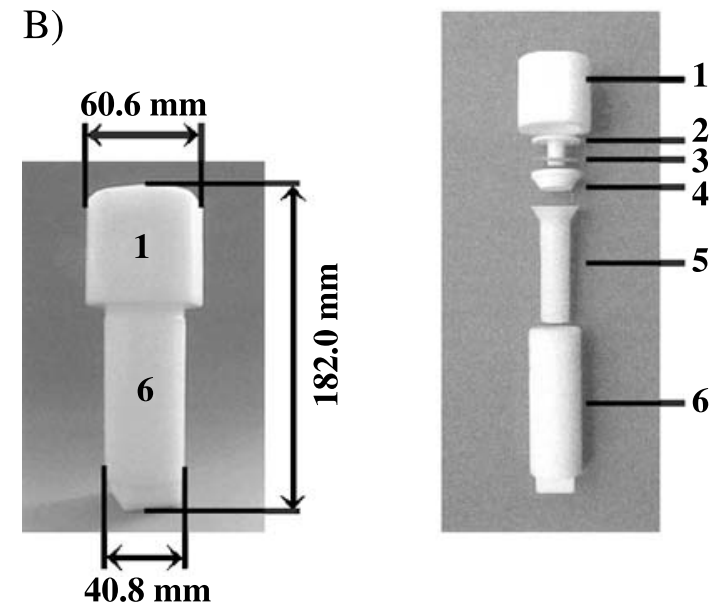

C)

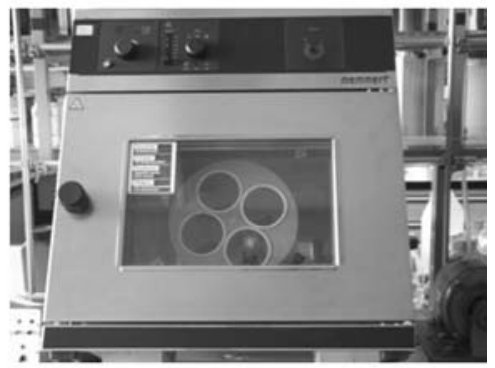

Fig. 11. Experimental setup: A) cylindrical PTFE vessel, left: front view, right: top view; B) PTFE pressure vessel, MLS GmbH, HPV80, 50 ml, 60 bar, left: assembled PTFE pressure vessel, right: dismantling of the PTFE pressure vessel: 1) screw cap, 2) pressure plate, 3) elastomer ring, 4) lid with 2, 3, and $4 \mathrm{~mm}$ rupture discs, 5) insert, 6) pressure vessel with a wall thickness of $10.05 \mathrm{~mm}$;

C) oven with rotating device

aluminate solution cool to room temperature, we added it to the colloidal silica suspension under vigorous stirring and continued stirring for 3 to $6 \mathrm{~min}$. The resulting homogeneous opaque gel is the final gel before crystallization. This gel was then transferred into a cylindrical poly(tetrafluoroethylene) $(P T F E)$ vessel, which was itself placed in a tight PTFE pressure vessel. Crystallization took place at $160^{\circ} \mathrm{C}$ in an oven equipped with a rotating device for allowing the application of dynamic conditions (see Fig. 11). The rotating device consists of a holder for the pressure vessels and is mounted at an angle of approximately $30^{\circ}$. The rotation during crystallization was found to considerably reduce the reaction time [14]. For dynamic conditions, a rotation speed of $20 \mathrm{~min}^{-1}$ was typically applied.

After crystallization the pressure vessel was cooled in ice for $1 \mathrm{~h}$ before opening. The product was washed several times with approximately $250 \mathrm{ml}$ of boiling water and centrifuged until the $p H$ of the supernatant became neutral. The crystals were dried for approximately $16 \mathrm{~h}$ at $80^{\circ} \mathrm{C}$ in air yielding between 5 and $8 \mathrm{~g}$ of material. Subsequent ion exchange was performed by suspending the material in $70 \mathrm{ml}$ of water and adding $4.0 \mathrm{~g}$ of $\mathrm{KNO}_{3}$. After stirring this suspension for $5 \mathrm{~h}$ at about $50^{\circ} \mathrm{C}$, we washed and centrifuged it until the $\mathrm{pH}$ of the supernatant became neutral. Finally, the crystals were dried in air for $16 \mathrm{~h}$ at $80^{\circ} \mathrm{C}$. A typical variation of this procedure is the change of the composition of the starting gel, specifically $\mathrm{K}_{2} \mathrm{O} / \mathrm{Al}_{2} \mathrm{O}_{3}$ and $\mathrm{H}_{2} \mathrm{O} / \mathrm{Al}_{2} \mathrm{O}_{3}$ ratios.

We followed a slightly different procedure to obtain $6 \mu \mathrm{m}$ crystals (see Fig. 12). The potassium aluminate solution was prepared as follows: Potassium hydroxide was added to water and stirred at $0^{\circ} \mathrm{C}$ 


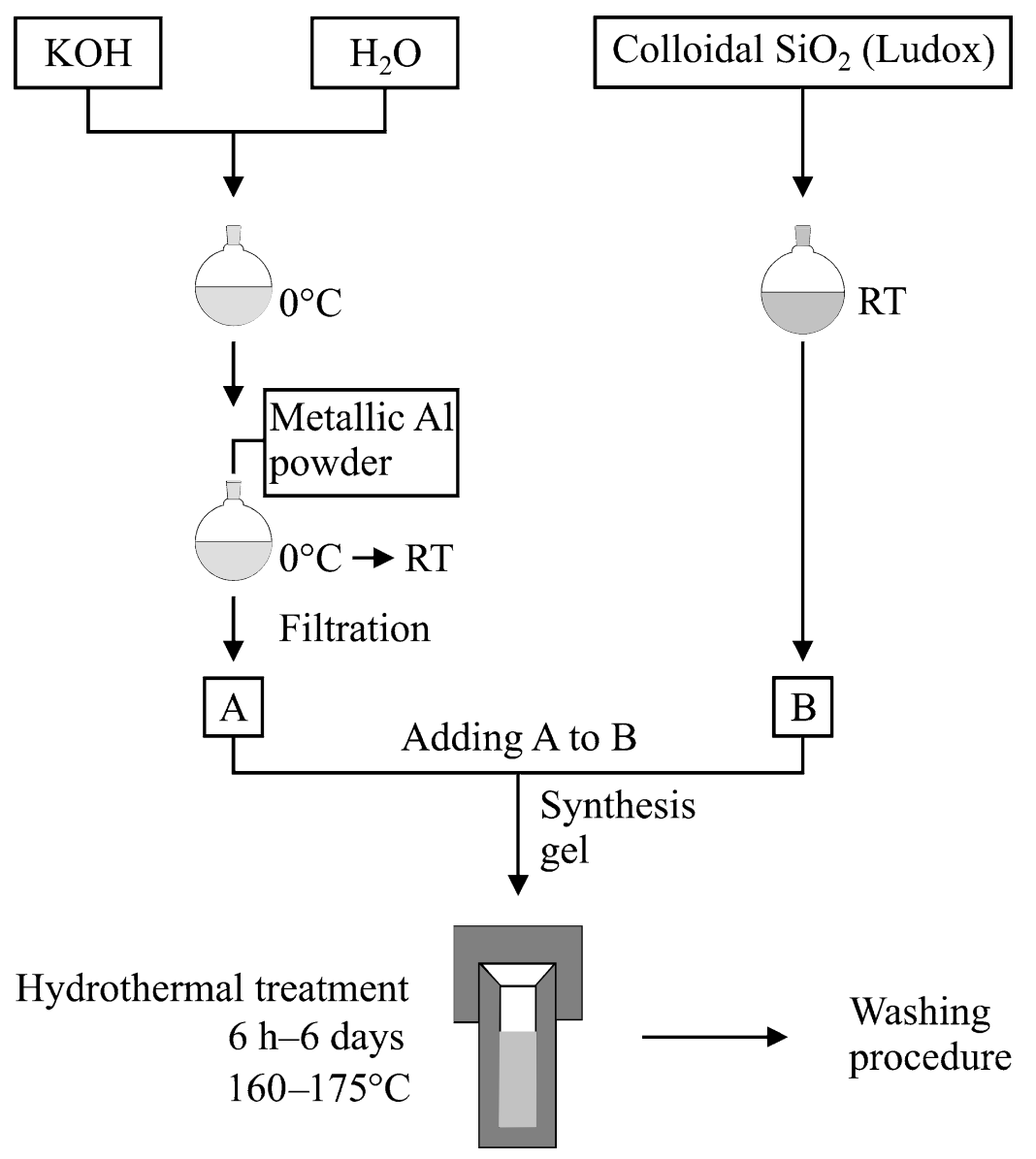

Fig. 12. Synthesis procedure for obtaining $6 \mu \mathrm{m}$ zeolite L crystals

(on ice) for $5 \mathrm{~min}$. Next, metallic aluminum powder was added under a $\mathrm{N}_{2}$ flow and stirred at $0^{\circ} \mathrm{C}$ for further $15 \mathrm{~min}$. After letting the solution warm to room temperature, it was stirred at this temperature for $1.5 \mathrm{~h}$ under $\mathrm{N}_{2}$. The resulting solution was filtered for removing $\mathrm{Fe}(\mathrm{OH})_{3}$, which is due to $\mathrm{Fe}$ as an impurity in $\mathrm{Al}$, until a clear solution was obtained (between one and two times). This solution was added to the silica suspension (Ludox) under stirring. The final gel was transferred to the PTFE vessel for crystallization at $175^{\circ} \mathrm{C}$ for $72 \mathrm{~h}$ under static conditions. Recovering of the product was conducted as explained above.

For the synthesis of small zeolite L crystals we applied the usual procedure except for adding $\mathrm{KOH}$ to the silica colloidal suspension in order to increase the alkalinity of the starting gel. Potassium-silica suspension and potassium-aluminate solution were refluxed separately for $15 \mathrm{~h}$ before mixing. Another possibility to reduce the size of the zeolite $\mathrm{L}$ crystals is by adding $\mathrm{Mg}^{2+}$ to the silica suspension.

\section{Characterization}

The following experiment was performed to conveniently check the success of a zeolite L synthesis. When zeolite $\mathrm{L}$ is added to an aqueous solution of thionine, aggregates of the dye immediately form on the external zeolite surface [18]. Upon boiling the sample for about $1 \mathrm{~min}$ a sudden colour change from violet to blue is observed. This effect is due to the insertion of the dye molecules into the zeolite $\mathrm{L}$ channels where they can exist as monomers only. The blue colour remains after cooling to room temperature. If the test is negative (no colour change), the more involved characterization measurements 
can be skipped. We have found that the thionine test is very reliable, except for very small crystals, where the results are not always conclusive.

The materials were analysed by X-ray powder diffraction XRD (Guinier-camera de Wolff Mk.IV, $\mathrm{CuK} \alpha$ radiation, ENRAF-NONIUS) for phase identification. The obtained patterns were compared with a standard pattern of commercial zeolite L (Union Carbide or/and UOP). The morphology of the crystalline phase was examined by means of scanning electron microscopy SEM (JOEL JSM 840 and Hitachi S-3000N). Small crystals were examined by transmission electron microscopy TEM (Hitachi H-600-2 and Philips XL30 ESEM-FEG). Energy dispersive X-ray measurements EDX (NORAN TN 5402 and NORAN SIX NSS200) allowed for the determination of the elemental composition of the products.

\section{Acknowledgements}

We appreciate the assistance of Dr. Massoud Dadras (Institute of Microtechnology, University of Neuchâtel) for the acquisition of TEM images and his helpful advice concerning electron microscopy. We also acknowledge the kind support of Beatrice Frey (SEM and XRD) and René Bühler (expertise in zeolite synthesis). Financial support was provided by the Swiss Federal Office of Energy (project nr. 36846), the "Stiftung der Portland Cementfabrik Laufen, Switzerland", and the Swiss Federal Office for Education and Science (European Union Research Training Network Nanochannel).

\section{References}

[1] Brühwiler D, Calzaferri G (2004) Microporous Mesoporous Mater 72: 1

[2] Schulz-Ekloff G, Wöhrle D, van Duffel B, Schoonheydt RA (2002) Microporous Mesoporous Mater 51: 91

[3] Hashimoto S (2003) J Photochem Photobiol C: Photochem Rev 4: 19

[4] a) Breck DW (1974) Zeolite Molecular Sieves. Wiley, New York; b) Baerlocher C, Meier WM, Olson DH (2001) Atlas of Zeolite Framework Types. Elsevier

[5] a) Ohsuna T, Horikawa Y, Hiraga K, Terasaki O (1998) Chem Mater 10: 688; b) Ohsuna T, Slater B, Gao F, Yu J, Sakamoto Y, Zhu G, Terasaki O, Vaughan DEW, Qiu S, Catlow CRA (2004) Chem Eur J 10: 5031

[6] Calzaferri G, Huber S, Maas H, Minkowski C (2003) Angew Chem Int Ed 42: 3732

[7] Pauchard M, Huber S, Méallet-Renault R, Maas H, Pansu R, Calzaferri G (2001) Angew Chem Int Ed 40: 2839

[8] Calzaferri G, Maas H, Pauchard M, Pfenniger M, Megelski S, Devaux A (2002) Advances in Photochemistry 27: 1

[9] Ha K, Park JS, Oh KS, Zhou YS, Chun YS, Lee YJ, Yoon KB (2004) Microporous Mesoporous Mater 72: 91

[10] Robson H, Lillerud KP (2001) Verified Syntheses of Zeolitic Materials. Elsevier

[11] Meng X, Zhang Y, Meng C, Pang W (1993) Proc 9th Int Zeolite Conf. Montreal, p 297

[12] a) Tsapatsis M, Okubo T, Lovallo M, Davis ME (1995) Mater Res Soc Symp Proc 371: 21; b) Tsapatsis M, Lovallo M, Okubo T, Davis ME, Sadakata M (1995) Chem Mater 7: 1734

[13] Verduijn JP (1996) US Patent 5491119

[14] Megelski S, Calzaferri G (2001) Adv Funct Mater 11: 277

[15] Ko YS, Chang SH, Ahn WS (2001) Stud Surf Sci Catal 135: 279

[16] Calzaferri G, Pauchard M, Maas H, Huber S, Khatyr A, Schaafsma T (2002) J Mater Chem 12: 1

[17] Pfenniger M, Calzaferri G (2000) Chem Phys Chem 1: 211

[18] Calzaferri G, Brühwiler D, Megelski S, Pfenniger M, Pauchard M, Hennessy B, Maas H, Devaux A, Graf U (2000) Solid State Sciences 2: 421 